\title{
Alterations in transcriptional responses associated with vascular
} aging

\author{
Yumei Zhan, Lei Yuan and Peter Oettgen*
}

Address: Division of Cardiology, and Molecular and Vascular Biology, Department of Medicine, Center for Vascular Biology Research, Beth Israel Deaconess Medical Center, Boston, Massachusetts, USA

Email: Yumei Zhan - yzhan@caregroup.harvard.edu; Lei Yuan - lyuan1@bidmc.harvard.edu; Peter Oettgen* - joettgen@bidmc.harvard.edu

* Corresponding author

Published: 21 May 2009

Journal of Inflammation 2009, 6:16 doi:10.1186/1476-9255-6-16
Received: 5 March 2009

Accepted: 2I May 2009

This article is available from: http://www.journal-inflammation.com/content/6/1/16

(C) 2009 Zhan et al; licensee BioMed Central Ltd.

This is an Open Access article distributed under the terms of the Creative Commons Attribution License (http://creativecommons.org/licenses/by/2.0), which permits unrestricted use, distribution, and reproduction in any medium, provided the original work is properly cited.

\begin{abstract}
Vascular aging is an independent risk factor for cardiovascular disease that can occur in the absence of other traditional risk factors. Inflammation is a hallmark of vascular aging that ultimately leads to structural changes in the vessel wall including an increase in medial thickness and perivascular fibrosis. Several classes of transcription factors have been identified that participate in the regulation of cellular responses associated with vascular aging. Nuclear factor (NF)- $\mathrm{KB}$ is the prototypic example of a transcriptional activator in the setting of inflammation, being activated in response to multiple inflammatory mediators including pro-inflammatory cytokines and bacterial endotoxin. In contrast, the activation of the nuclear hormone receptor and transcription factor peroxisome proliferator-activated receptor-alpha (PPAR- $\alpha$ ) results in its translocation from the cell surface to the nucleus where it exerts anti-inflammatory effects. Vascular aging is also associated with endothelial dysfunction. One important repair mechanism for improving endothelial function is the recruitment of endothelial progenitor cells (EPCs). In the setting of aging the number of EPCs diminishes which has been linked to a decrease in the activity and/or expression of the transcription factor hypoxia inducible factor (HIF)-I alpha. A change in the balance of the activity of pro-inflammatory transcription factors versus those that inhibit inflammation likely contributes to the process of vascular aging. The purpose of this review is to summarize our current knowledge of these age-related changes in transcriptional responses, and to discuss the therapeutic potential of targeting some of these factors.
\end{abstract}

\section{Arterial aging}

Epidemiological studies strongly support that vascular aging, which is accompanied by increased arterial stiffness, is an independent risk factor for cardiovascular morbidity and mortality [1-4]. Arterial stiffness is also frequently associated with the presence or the development of hypertension $[5,6]$. Whether an increase in arterial stiffness always precedes the onset of hypertension has not been determined. Although the precise molecular mechanisms under- lying arterial aging have not been elucidated, inflammation appears to be a central component [7-9]. Some of the mediators of this inflammatory response include pro-inflammatory cytokines such as tumor necrosis alpha (TNF- $\alpha$ ), transforming growth factor-beta (TGF- $\beta$ ), and angiotensin II (Ang II). The focus of this article is to review some of the transcriptional mediators that are responsible for activating critical genes involved in the initiation and propagation of vascular aging (Table 1 ). 
Table I: Roles of selected transcription factors in vascular inflammation and aging

\begin{tabular}{llll}
\hline Transcription Factors & Pro-/Anti-inflammatory & Selected Target Genes & Alterations with Aging \\
\hline NF- $K B$ & Pro-inflammatory & MCP-I, ICAM-I, NOS2 & Increased \\
\hline HIF-I $\alpha$ & Anti-inflammatory & VEGF, SDF-I & Decreased \\
\hline Ets-I & Pro-inflammation & MCP-I, VCAM-I, PDGF, pI6INK4a & Increased \\
\hline ERG & Anti-inflammatory & VWF, VE-Cad, Ang2, IL-8 & Unknown \\
\hline PPAR- $\alpha,-\gamma$ & Pro-inflammatory & NF-|B, pro-inflammatory cytokines, NOS2, VCAM-I & Decreased \\
\hline
\end{tabular}

\section{NF- $\kappa$ B}

$\mathrm{NF}-\kappa \mathrm{B}$ is known as the prototypic transcriptional mediator of inflammation. Under non-inflammatory conditions the heterdimeric Rel domain subunits, p50 and p65, of NF- $\kappa \mathrm{B}$ are constitutively expressed but remain inactivated in the cytoplasm bound to the inhibitory protein Iк$B$. In response to inflammation I $\kappa-B$ is degraded allowing p50 and p65 to form NF- $\kappa$ B that can now freely translocate to the nucleus [10]. It was recently demonstrated that not only the expression but the activity of NF- $\kappa \mathrm{B}$ is up-regulated during the process of aging $[11,12]$. The expression and activity of NF- $\kappa \mathrm{B}$ was evaluated in fibroblasts from patients with ages ranging from 22 to 92 years of age. Over time there was a significant increase in the activity of NF$\kappa \mathrm{B}$ and the expression of inflammatory genes.

During the process of vascular aging there is a similar increase in $\mathrm{NF}-\kappa \mathrm{B}$ expression and activity in vascular smooth muscle cells and endothelial cells. This has been attributed to a variety of different mechanisms [13]. First, there is an increase in the levels of circulating cytokines, and in particular TNF- $\alpha$ during the process of aging. Second, vascular aging is associated with the increased production of reactive oxygen species (ROS), and in particular mitochondrial-derived $\mathrm{H}_{2} \mathrm{O}_{2}$ due to age-related mitochondrial dysfunction $[12,14,15]$. In the vascular endothelium age related increases in the expression of NF$\kappa \mathrm{B}$ are associated with increased expression of monocyte chemoattractant protein 1 (MCP-1) and a reduction in endothelium-dependent dilation [16]. Similarly the activity and response of $\mathrm{NF}-\kappa \mathrm{B}$ to pro-inflammatory cytokines was enhanced in aged compared to young vascular smooth muscle cells and was associated with an augmentation of the induction of ICAM-1 and inducible nitric oxide synthase (NOS2) genes [17].

\section{Hypoxia Inducible Factor-I alpha (HIF-I $\alpha$ )}

HIF- $1 \alpha$ is a member of the transcription factor family and has been shown to be a critical regulator of neovascularization [18]. HIF-1 $\alpha$ is activated in the setting of hypoxia and promotes the expression of vascular endothelial growth factor (VEGF) [19]. In the setting of myocardial ischemia or infarction the activation of HIF-1 $\alpha$ promotes local angiogenesis through the expression of VEGF. In addition HIF- $1 \alpha$ can induce the expression of stromal cellderived factor-1 (SDF-1) [20]. SDF-1 enhances the recruitment of endothelial progenitor cells (EPCs) in the setting of tissue injury or ischemia. One of the hallmarks of vascular aging is endothelial dysfunction. EPCs can promote the repair of dysfunctional or damaged endothelium. Recent studies suggest that the levels and activity of HIF$1 \alpha$ diminish with aging and thereby leads to reduced levels of SDF-1 [21,22]. The results of these studies suggest that both local proliferation of endothelial cells by VEGF in the setting of ischemia, and the recruitment of EPCs to promote neovascularization or repair damaged endothelium are diminished with aging.

\section{ETS factor family}

The ETS factors are a family of transcription factors that share a highly conserved DNA binding domain (Ets domain). ETS factors are involved in regulating a wide variety of biological processes including normal development and differentiation [23]. Until recently, very little was known about a role for ETS factors in regulating vascular inflammation. Over the past few years several studies have been completed that support a role for several ETS family members in the regulation of vascular inflammation, including endothelial activation in response to inflammatory mediators, the recruitment of inflammatory cells to the vessel wall, and proliferation and migration of vascular smooth muscle cells. We and others have observed that Ets-1 is induced in VSMC and endothelial cells in response to a variety of stimuli including Angiotensin II (Ang II), PDGF-BB, thrombin, interleukin-1 beta (IL-1 $\beta$ ), and tumor necrosis alpha (TNF- $\alpha$ ) [24-30]. Target genes identified to be downstream of Ets- 1 in the setting of acute vascular inflammation include the chemokine MCP-1 and the adhesion molecule VCAM-1. Systemic administration of the vasoactive peptide Ang II via continuous infusion is not only associated with increases in blood pressure but also promotes the recruitment of 
inflammatory cells, including T cells and monocytic cells, to the vessel wall. The influx of inflammatory cells in response to Ang II is markedly diminished in Ets-1 deficient mice compared to littermate controls[27]. One of the major mediators of vascular inflammation within the vessel wall is ROS. Ang II, for example, promotes the generation of superoxide anions in VSMC largely via the activity of NADPH oxidases, that can be converted to hydrogen peroxide by superoxide dismutase [31]. Reactive oxygen species, and in particular hydrogen peroxide, can also stimulate Ets-1 expression [32]. Ets-1 functions synergistically with the transcription factor $\mathrm{Sp} 1$ to regulate the expression of the PDGF receptor in an ROS-dependent manner. Ets-1 and Sp1 are enriched in VSMC found in human atherosclerotic lesions that express increased levels of the PDGF receptor.

The tumor suppressor molecule $\mathrm{p} 16^{\mathrm{INK} 4 \mathrm{a}}$ is a principal mediator of cellular senescence $[33,34]$. Increased levels of p16 $6^{\text {INK4a }}$ have been detected in a number of different cell types associated with aging including vascular smooth muscle cells [35]. The molecular mechanisms by which p $16^{\text {INK4a }}$ is regulated have not been fully elucidated, however at the transcriptional level it has recently been shown that Ets- 1 is a critical factor in determining expression levels of p16 ${ }^{\text {INK4a }}$ in a number of cells and tissues during the process of aging [36]. The age related increases in the expression of Ets- 1 and p $16^{\text {INK4a }}$ are diminished by caloric restriction that is associated with weight gain. Administration of resveratrol, a natural atoxic phytoestrogen, to mice, mimics the transcriptional effects of caloric restriction [37]. Resveratrol is an activator of sirtuins (SIRT1). Sirtuins are a family of $\mathrm{NAD}^{+}$-dependent deacetylases that can inhibit cell senescence. Resveratrol has been shown to reduce the levels of p16 ${ }^{\text {INK4a }}$ through activation of SIRT1 [38]. The administration of resveratrol to mice, prevented age related reductions in endothelial function [37]. Resveratrol is a potent inhibitor of NF- $\kappa \mathrm{B}$ activation in endothelial cells [39]. Similarly in obese mice, that exhibit a more rapid decline in vascular function that is associated with a pro-inflammatory state, administration of resveratrol reduced the obesity related endothelial dysfunction, that was at least in part related to a reduction in the generation of ROS [37].

ERG is an ETS family member that has been shown to contribute to the regulation of a number of endothelialrestricted genes including VE-cadherin, $\mathrm{VWF}$, and angiopoietin-2 [40-42]. ERG is markedly downregulated in human endothelial cells in response to TNF- $\alpha$. We have recently demonstrated that ERG functions as a suppressor of EC activation [43]. Suppression of ERG using siRNA results in an increase in neutrophil attachment that is dependent on increased expression of interleukin- 8 by endothelial cells. A significant number of genes that are up or down regulated by ERG suppression in endothelial cells overlap with genes that are similarly up or down regulated by TNF- $\alpha$.

\section{PPAR family}

More recently selected transcription factors have been identified that exhibit anti-inflammatory properties and can modulate the initial cascade of genes induced in response to inflammatory stimuli. For example, the PPAR (peroxisome proliferators-activated receptors) nuclear receptors are transcription factors expressed in EC, VSMC, and monocytic cells. Activation of PPAR $\alpha$ and PPAR $\gamma$ receptors are associated with favorable effects on lipid metabolism and insulin sensitivity that are also beneficial with regard to limiting the development of atherosclerosis [44]. Binding of PPAR agonists to their cognate receptors is also associated with anti-inflammatory effects. Activation of the PPAR $\gamma$ pathway, for example, can inhibit the activity of the transcription factors AP- 1 and NF- $\mathrm{KB}$ in response to pro-inflammatory cytokines such as TNF- $\alpha$ in endothelial cells [45]. Activation of PPAR $\gamma$ also inhibits the process of vascular aging in rats $[46,47]$. For example, the administration of the PPAR $\gamma$ agonist 2,4-thiazolidinedione $(2,4-\mathrm{TZD})$ to rats of varying ages was associated with a reduction in the activity of NF- $\mathrm{kB}$, pro-inflammatory cytokines, NOS2, and vascular cell adhesion molecule-1 (VCAM-1) in the kidney. The upregulation of NF$\kappa \mathrm{B}$ and associated inflammatory genes in the absence of treatment is an aged related phenomenon.

\section{Targeting transcription factors}

The elucidation of the critical transcriptional factors that regulate vascular inflammation may therefore not only advance our basic understanding of the molecular mechanisms of vascular inflammation but may also provide novel therapeutic targets for drug discovery. Historically, transcription factors have not been viewed as good targets for drug therapy, with the exception of nuclear hormone receptors that often reside on the cell surface and are activated by ligands that promote their transfer into nucleus where they function as transcription factors and bind to specific gene targets. One approach that has been used to target transcription factors in vivo is through the development of membrane permeable peptides that can competitively inhibit the binding of the transcription factors to the DNA. This approach was used to block the function of the ETS factor ELF-1 to inhibit the expression of the endothelial restricted genes Tie2 and endothelial nitric oxide synthase (eNOS) and block tumor angiogenesis in vivo [48]. A similar approach was used in vivo to block the activity of Ets- 1 and inhibit the generation of ROS, induction of inflammatory genes, and favorably effect vascular remodeling in response to Ang II infusion in mice over two weeks [49]. The ability to identify small molecules that specifically block transcription factors that are not lig- 
and-dependent has recently demonstrated [50]. Although only a few transcription factors have been targeted in this way, and no drugs, with the exception of those targeting the nuclear hormone receptors, are currently available to block these factors, several companies are actively pursuing these factors as therapeutic targets.

\section{Competing interests}

The authors declare that they have no competing interests.

\section{Authors' contributions}

YZ contributed to the writing of this manuscript. LJ contributed to the writing of this manuscript. PO contributed to the writing of this manuscript. All authors read and approved the final manuscript.

\section{Acknowledgements}

This work was supported by NIH grant POI HL76540 (PO), ROI HL0827I7 (PO), the AHA Established Investigator Award EIA07400I2 (PO), and T32 training grant HL07374-26 (YZ)

\section{References}

I. Breithaupt-Grogler K, Belz GG: Epidemiology of the arterial stiffness. Pathol Biol (Paris) 1999, 47:604-6I3.

2. Benetos A, Waeber B, Izzo J, Mitchell G, Resnick L, Asmar R, Safar M: Influence of age, risk factors, and cardiovascular and renal disease on arterial stiffness: clinical applications. Am J Hypertens 2002, 15:1101-II08.

3. Wang X, Keith JC Jr, Struthers AD, Feuerstein GZ: Assessment of arterial stiffness, a translational medicine biomarker system for evaluation of vascular risk. Cardiovasc Ther 2008, 26:2 I 4-223.

4. Najjar SS, Scuteri A, Lakatta EG: Arterial aging: is it an immutable cardiovascular risk factor? Hypertension 2005, 46:454-462.

5. Lekakis JP, Zakopoulos NA, Protogerou AD, Papaioannou TG, Kotsis VT, Pitiriga V, Tsitsirikos MD, Stamatelopoulos KS, Papamichael CM, Mavrikakis ME: Arterial stiffness assessed by pulse wave analysis in essential hypertension: relation to $24-\mathrm{h}$ blood pressure profile. Int / Cardiol 2005, 102:391-395.

6. Safar H, Chahwakilian A, Boudali Y, Debray-Meignan S, Safar M, Blacher J: Arterial stiffness, isolated systolic hypertension, and cardiovascular risk in the elderly. Am J Geriatr Cardiol 2006, 15: I78-182.

7. Mahmud A, Feely J: Arterial stiffness is related to systemic inflammation in essential hypertension. Hypertension 2005, 46: $1118-1122$

8. Wang M, Zhang J, Jiang LQ, Spinetti G, Pintus G, Monticone R, Kolodgie FD, Virmani R, Lakatta EG: Proinflammatory profile within the grossly normal aged human aortic wall. Hypertension 2007, 50:219-227.

9. Pepe S, Lakatta EG: Aging hearts and vessels: masters of adaptation and survival. Cardiovasc Res 2005, 66:190-193.

10. Baeuerle PA, Baltimore D: NF-kappa B: ten years after. Cell 1996, 87:13-20.

II. Kriete A, Mayo KL: Atypical pathways of NF-kappaB activation and aging. Exp Gerontol 2009, 44:250-5

12. Ungvari Z, Orosz Z, Labinskyy N, Rivera A, Xiangmin Z, Smith K, Csiszar A: Increased mitochondrial $\mathrm{H2O} 2$ production promotes endothelial NF-kappaB activation in aged rat arteries. Am J Physiol Heart Circ Physiol 2007, 293:H37-47.

13. Csiszar A, Wang M, Lakatta EG, Ungvari Z: Inflammation and endothelial dysfunction during aging: role of NF-kappaB. J Appl Physiol 2008, 105: I333-1341.

14. Kriete A, Mayo KL, Yalamanchili N, Beggs W, Bender P, Kari C, Rodeck U: Cell autonomous expression of inflammatory genes in biologically aged fibroblasts associated with elevated NF-kappaB activity. Immun Ageing 2008, 5:5.

15. Csiszar A, Labinskyy N, Smith K, Rivera A, Orosz Z, Ungvari Z: Vasculoprotective effects of anti-tumor necrosis factor-alpha treatment in aging. Am J Pathol 2007, 170:388-398.
16. Donato AJ, Eskurza I, Silver AE, Levy AS, Pierce GL, Gates PE, Seals DR: Direct evidence of endothelial oxidative stress with aging in humans: relation to impaired endothelium-dependent dilation and upregulation of nuclear factor-kappaB. Circ Res 2007, 100:1659-1666.

17. Yan ZQ, Sirsjo A, Bochaton-Piallat ML, Gabbiani G, Hansson GK: Augmented expression of inducible NO synthase in vascular smooth muscle cells during aging is associated with enhanced NF-kappaB activation. Arterioscler Thromb Vasc Biol 1999, 19:2854-2862

18. Wang GL, Jiang BH, Rue EA, Semenza GL: Hypoxia-inducible factor $I$ is a basic-helix-loop-helix-PAS heterodimer regulated by cellular O2 tension. Proc Natl Acad Sci USA I 995, 92:55 10-55 I 4.

19. Forsythe JA, Jiang BH, lyer NV, Agani F, Leung SW, Koos RD, Semenza GL: Activation of vascular endothelial growth factor gene transcription by hypoxia-inducible factor I. Mol Cell Biol 1996, 16:4604-46|3.

20. Karshovska E, Zernecke A, Sevilmis G, Millet A, Hristov M, Cohen $C D$, Schmid H, Krotz F, Sohn HY, Klauss V, Weber C, Schober A: Expression of HIF-Ialpha in injured arteries controls SDFIalpha mediated neointima formation in apolipoprotein $E$ deficient mice. Arterioscler Thromb Vasc Biol 2007, 27:2540-2547.

21. Loh SA, Chang El, Galvez MG, Thangarajah H, El-ftesi S, Vial IN, Lin DA, Gurtner GC: SDF-I alpha expression during wound healing in the aged is HIF dependent. Plast Reconstr Surg 2009, I 23:65S-75S.

22. Hoenig MR, Bianchi C, Rosenzweig A, Sellke FW: Decreased vascular repair and neovascularization with ageing: mechanisms and clinical relevance with an emphasis on hypoxia-inducible factor-I. Curr Mol Med 2008, 8:754-767.

23. Wasylyk B, Hahn SL, Giovane A: The Ets family of transcription factors. Eur J Biochem 1993, 21 I:7-18.

24. Hultgardh-Nilsson A, Cercek B, Wang JW, Naito S, Lovdahl C, Sharifi $B$, Forrester JS, Fagin JA: Regulated expression of the ets-I transcription factor in vascular smooth muscle cells in vivo and in vitro. Circ Res 1996, 78:589-595.

25. Goetze S, Kintscher U, Kaneshiro K, Meehan WP, Collins A, Fleck E, Hsueh WA, Law RE: TNFalpha induces expression of transcription factors c-fos, Egr-I, and Ets- I in vascular lesions through extracellular signal-regulated kinases I/2. Atherosclerosis 200I, 159:93-101.

26. Naito S, Shimizu S, Maeda S, Wang J, Paul R, Fagin JA: Ets-I is an early response gene activated by ET-I and PDGF-BB in vascular smooth muscle cells. Am J Physiol 1998, 274:C472-480.

27. Zhan Y, Brown C, Maynard E, Anshelevich A, Ni W, Ho IC, Oettgen $P$ : Ets- $I$ is a critical regulator of Ang II-mediated vascular inflammation and remodeling. J Clin Invest 2005, I I 5:2508-25 I6.

28. Redlich K, Kiener HP, Schett G, Tohidast-Akrad M, Selzer E, Radda I, Stummvoll GH, Steiner CW, Groger M, Bitzan P, Zenz P, Smolen JS, Steiner G: Overexpression of transcription factor Ets-I in rheumatoid arthritis synovial membrane: regulation of expression and activation by interleukin- $I$ and tumor necrosis factor alpha. Arthritis Rheum 200I, 44:266-274.

29. Liu AY, Corey E, Vessella RL, Lange PH, True LD, Huang GM, Nelson PS, Hood L: Identification of differentially expressed prostate genes: increased expression of transcription factor ETS-2 in prostate cancer. Prostate 1997, 30:145-153.

30. Santiago FS, Khachigian LM: Ets-I stimulates platelet-derived growth factor A-chain gene transcription and vascular smooth muscle cell growth via cooperative interactions with SpI. Circ Res 2004, 95:479-487.

3I. Griendling KK, Sorescu D, Ushio-Fukai M: NAD(P)H oxidase: role in cardiovascular biology and disease. Circ Res 2000, 86:494-50I.

32. Bonello MR, Bobryshev YV, Khachigian LM: Peroxide-inducible Ets-I mediates platelet-derived growth factor receptoralpha gene transcription in vascular smooth muscle cells. Am J Pathol 2005, 167: II49-1I59.

33. Palmero I, McConnell B, Parry D, Brookes S, Hara E, Bates S, Jat P, Peters G: Accumulation of pI6INK4a in mouse fibroblasts as a function of replicative senescence and not of retinoblastoma gene status. Oncogene 1997, 15:495-503.

34. Baker DJ, Perez-Terzic C, Jin F, Pitel K, Niederlander NJ, Jeganathan K, Yamada S, Reyes S, Rowe L, Hiddinga HJ, Eberhardt NL, Terzic A, van Deursen JM: Opposing roles for p/6Ink4a and p/9Arf in 
senescence and ageing caused by BubRI insufficiency. Nat Cell Biol 2008, 10:825-836.

35. Rodriguez-Menocal L, Pham SM, Mateu D, St-Pierre M, Wei Y, Pestana I, Aitouche A, Vazquez-Padron RI: Aging increases pl6Ink4a expression in vascular smooth muscle cells. BiosciRep 2009 in press.

36. Krishnamurthy J, Torrice C, Ramsey MR, Kovalev GI, Al-Regaiey K, Su L, Sharpless NE: Ink4a/Arf expression is a biomarker of aging. J Clin Invest 2004, I I 4: I 299- I307.

37. Pearson KJ, Baur JA, Lewis KN, Peshkin L, Price NL, Labinskyy N, Swindell WR, Kamara D, Minor RK, Perez E, Jamieson HA, Zhang Y, Dunn SR, Sharma K, Pleshko N, Woollett LA, Csiszar A, Ikeno Y, Le Couteur D, Elliott PJ, Becker KG, Navas P, Ingram DK, Wolf NS, Ungvari $Z$, Sinclair DA, de Cabo $R$ : Resveratrol delays age-related deterioration and mimics transcriptional aspects of dietary restriction without extending life span. Cell Metab 2008, 8:157-168

38. Huang J, Gan Q, Han L, Li J, Zhang H, Sun Y, Zhang Z, Tong T: SIRT I overexpression antagonizes cellular senescence with activated ERK/S6kI signaling in human diploid fibroblasts. PLoS ONE 2008, 3:el710.

39. Csiszar A, Smith K, Labinskyy N, Orosz Z, Rivera A, Ungvari Z: Resveratrol attenuates TNF-alpha-induced activation of coronary arterial endothelial cells: role of NF-kappaB inhibition. Am J Physiol Heart Circ Physiol 2006, 291:HI694-1699.

40. Hasegawa Y, Abe M, Yamazaki T, Niizeki O, Shiiba K, Sasaki I, Sato Y: Transcriptional regulation of human angiopoietin-2 by transcription factor Ets-I. Biochem Biophys Res Commun 2004, 31 6:52-58.

4I. Schwachtgen JL, Janel N, Barek L, Duterque-Coquillaud M, Ghysdael J, Meyer D, Kerbiriou-Nabias D: Ets transcription factors bind and transactivate the core promoter of the von Willebrand factor gene. Oncogene 1997, 15:3091-3102.

42. Birdsey GM, Dryden NH, Amsellem V, Gebhardt F, Sahnan K, Haskard DO, Dejana E, Mason JC, Randi AM: Transcription factor Erg regulates angiogenesis and endothelial apoptosis through VE-cadherin. Blood 2008, I I I:3498-3506.

43. Yuan L, Nikolova-Krstevski V, Zhan Y, Kondo M, Bhasin M, Varghese L, Yano K, Carman CV, Aird WC, Oettgen P: Antiinflammatory Effects of the ETS Factor ERG in Endothelial Cells Are Mediated Through Transcriptional Repression of the Interleukin8 Gene. Circ Res 2009, I04:1049-1057.

44. Plutzky J: Medicine. PPARs as therapeutic targets: reverse cardiology? Science 2003, 302:406-407.

45. Wang N, Verna L, Chen NG, Chen J, Li H, Forman BM, Stemerman MB: Constitutive activation of peroxisome proliferator-activated receptor-gamma suppresses pro-inflammatory adhesion molecules in human vascular endothelial cells. J Biol Chem 2002, 277:34176-34181.

46. Sung B, Park S, Yu BP, Chung HY: Modulation of PPAR in aging, inflammation, and calorie restriction. J Gerontol A Biol Sci Med Sci 2004, 59:997-1006.

47. Sung B, Park S, Yu BP, Chung HY: Amelioration of age-related inflammation and oxidative stress by PPARgamma activator: suppression of NF-kappaB by 2,4-thiazolidinedione. Exp Gerontol 2006, 41:590-599.

48. Huang X, Brown C, Ni W, Maynard E, Rigby AC, Oettgen P: Critical role for the Ets transcription factor ELF-I in the development of tumor angiogenesis. Blood 2006, 107:3153-3160.

49. Ni W, Zhan Y, He H, Maynard E, Balschi JA, Oettgen P: Ets-I Is a Critical Transcriptional Regulator of Reactive Oxygen Species and p47phox Gene Expression in Response to Angiotensin II. Circ Res 2007, I 0 I:985-94.

50. Koehler AN, Shamji AF, Schreiber SL: Discovery of an inhibitor of a transcription factor using small molecule microarrays and diversity-oriented synthesis. J Am Chem Soc 2003, | 25:8420-8421.

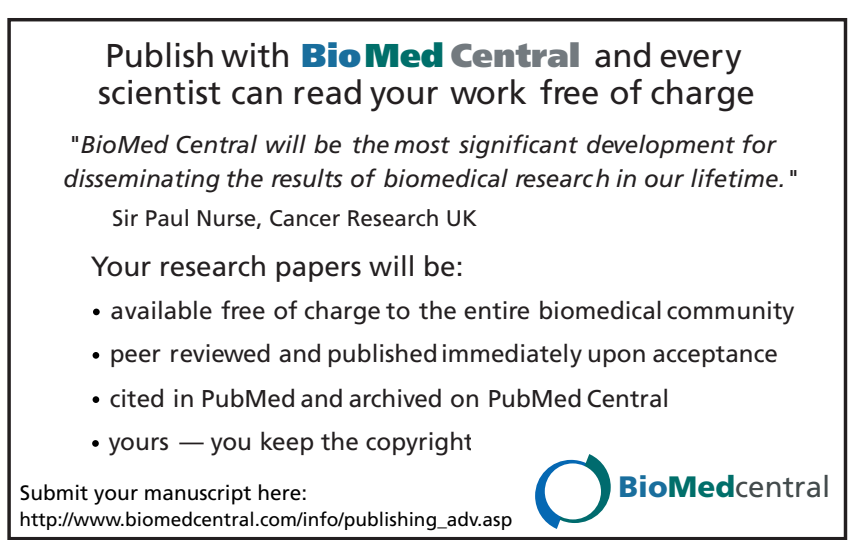

